\title{
Value Added Products from Dikiri Coconuts: Preparation, Compositional and Sensory Qualities
}

\author{
K.D.P.P. Gunathilake ${ }^{1 *}$, M.A. Mohammad Jaavidh², G.R.P.K. Perera ${ }^{3}$, Chamila Thilakahewa ${ }^{4}$, \\ A.A.N. Kumara ${ }^{1}$
}

\begin{abstract}
A study was conducted to evaluate Sri Lanka's dikiri coconut for toffees, Dikiri spread and ice cream. The prepared products were tested for their physico-chemical and sensory properties. Initial trials were done in Sri Lanka to identify the best Dikiri kernel/sugar ratio for toffees, showing that a 1:1 ratio gave acceptable quality. Prepared Dikiri spread was compared with margarine-based bread spread. Results revealed that the product was more acceptable in terms of taste and overall acceptability compared with the margarine-spread. The Dikiri spread comprised $7.95 \%$ minerals, $11.35 \%$ crude fat, $2.68 \%$ crude protein, $4.95 \%$ crude fiber and $73.07 \%$ carbohydrate on dry weight basis. Dikiri-added ice cream was acceptable and comparable with regular dairy ice cream. Composition of the Dikiri-added ice cream conforms to Sri Lanka Standards.
\end{abstract}

Keywords: Dikiri coconuts, Ice Cream, Toffees, Bread Spread, Proximate Composition, Sensory evaluation

${ }^{1}$ Coconut Processing Research Division, Coconut Research Institute, Bandirippuwa Estate, Lunuwila, Sri Lanka. *Current Address: 106/3, Palenwatta, Pannipitiya, Sri Lanka. *Email: kdppgunathilake@yahoo.com

${ }^{2}$ Department of Applied Nutrition, Wayamba University of Sri Lanka, Kuliyapitiya, Sri Lanka.

${ }^{3}$ Department of Food Science \& Technology, Faculty of Livestock, Fisheries \& Nutrition, Wayamba University of Sri Lanka.

${ }^{4}$ Dept. of Food Science \& Technology, Faculty of Agriculture, University of Peradeniya, Sri Lanka. 


\section{Introduction}

Dikiri is an abnormal coconut variety, mostly found in down south areas of Sri Lanka and the special feature of this coconut variety is the soft gelatinous amorphous kernel rich in energy and dietary fiber. The main dietary fiber components of Dikiri coconut were pectin and hemicelluloses while that of normal coconut was cellulose. Lignin content is comparatively low in dikiri coconut (Gunathilake, 2009). Similar abnormal characterized coconut varieties are also found in other counties. 'Makapuno' in Philippines, 'Kelapa Kopyor' in Indonesia and 'Thairu Thengai' in India are names of similar forms of coconut. The palms which bear such fruit possess a recessive gene and the Dikiri trait is not found in all the fruit of such palms.

In Sri Lanka Dikiri is consumed as raw or with juggary and also these nuts are sold to foreigners at higher prices. But there is no single value added product in the Sri Lankan market. In Philippines Makapuno is used to produce variety of desserts, sweets and as an ingredient of snack foods. Ready-to-serve succulent jam, bread spread, filling for pies and tarts and ice cream are some of the major products available in Philippines. According to Arancon (1996), Makapuno ice cream in Philippines is considered as one of the best flavored ice cream in the world and there is a huge demand gap for Makapuno coconut and Makapuno products In Philippines. So Dikiri coconut can be used as a substitute for this market opportunity. So, proper research and development is essential to enable full utilization of uncommon coconut resources like the Dikiri coconut. This study aimed at developing high quality value added products.

\section{Materials and method}

\section{Preparation:}

\section{Dikiri Toffee}

Preliminary trials were done (Note: indicate place in Sri Lanka and period research conducted) to identify best Dikiri pulp/sugar ratio (45\%/55\%, 50\%/50\% and 55\%/45\%), and it was found that $45 \% / 55 \%$ as the best. Sugar $(500 \mathrm{~g})$ was heated in a pan with little water and finely pasted dikiri kernel (500g) was added and the mixture was stirred well. While mixing, corn flour (25g), skim milk powder (25g) and ground cardamom $(2 \mathrm{~g})$ were added. The mixture was cooked while mixing to achieve a good consistency. Then this hot mixture was spread on an oiled tray applied with edible oil and cut into square shapes while mixture is hot and allowed to cool down to room temperature. The prepared toffees were packed in polythene container for further analysis.

\section{Dikiri Spread}

Dikiri pulp (1000g) was mixed with powdered white sugar $(700 \mathrm{~g})$, turmeric powder $(15 \mathrm{~g})$, salt powder $(100 \mathrm{~g})$ powdered cloves $(5 \mathrm{~g})$ and powdered cinnamon $(5 \mathrm{~g})$ and then corn flour (100g), powdered mustard (20g), powdered pepper $(20 \mathrm{~g})$, vinegar $(300 \mathrm{ml})$ and Vitamin E (200mg - $\infty$ tocopherol capsules) were added to mixture and the all ingredients were mixed thoroughly. The mixture was then filled in to pre-sterilized glass bottles (lug type) without leaving any air pockets and bottles were exhausted and pasteurized (after sealing the glass bottles) in boiling water bath for 10 and 30 minutes respectively. As a control, $1000 \mathrm{~g}$ commercial margarine (brand name 'Astra') was substituted for Dikiri kernel.

\section{Dikiri Ice Cream}

Fifty grams of Dikiri pulp was mixed with $100 \mathrm{~g}$ full cream milk powder (Brand name 'Anchor') and $500 \mathrm{ml}$ water and while mixing, finely ground sugar, margarine $(50 \mathrm{~g})$ and gelatine were added. Then this mixture was boiled for 3 minutes and immediately cooled down to room temperature and few drops of commercial vanilla essence (Delmege Brand) were added. Then the mixture was beaten and refrigerated for 1 hour in a brine bath, then the mixture was subjected to repeated beating in the brine bath and kept in the deep freezer $\left(-20^{\circ}\right.$ C).

\section{Compositional Analysis}

Moisture, protein, lipid, ash and crude fiber contents of dikiri toffees and bread spreads 
were determined following the standard methods of the Association of Official Analytical Chemists (1990). Total Carbohydrate content was calculated from the difference. All samples were analyzed at least in triplicate. Total Solids, acidity and fat content of dikiri ice cream were analyzed by using the laboratory techniques in food analysis described in Pearson (1973).

\section{Sensory Evaluation}

The modified 5-point Hedonic Scale was used to evaluate the toffee samples for sensory attributes; appearance, colour, taste, texture and overall acceptability by using 50 semi-trained panelists. Results of sensory evaluation were analyzed using a non-parametric Kruskal-Wallis Test in the Statistical Analysis System (SAS) software package.

Dikiri Spread samples were evaluated for sensory qualities, appearance, taste, texture and overall acceptability using 5 point Hedonic scale with 50-member semi trained panel and the results were analyzed using the Wilcoxon sign test in the Minitab version. The same procedure was used with thirty one panelists for the Sensory evaluation of Ice creams.

\section{Results and discussion}

\section{Dikiri Toffee}

Table 1 shows the sensory scores of dikiri toffee made with different proportions of dikiri kernel and sugar. According to the consumer preferences determined by the sensory evaluation, taste, texture and overall acceptability of toffees made with $45 \%$ dikiri (sample A) are significantly different to toffees made with higher proportions of dikiri coconut kernel.

Toffee is an emulsion of fat in an aqueous system and the basic structure of toffee is that of fat droplets dispersed in a sugar matrix. Skim milk powder was used as an emulsifier to stabilize fat distribution in the sugar mass. Corn flour was used to minimize the tendency to cold flow of fat, as dikiri coconut contains high fat and fibre. In sensory evaluation, it was observed that the scores for texture significantly reduced as the dikiri/ sugar ratio increased. According to Stansell in E.B.Jackson (1999), this may be due to the effect of high fat and fibre content of dikiri coconut in the emulsion and then the textural characteristics of the product.

Table 1. Sensory evaluation of dikiri toffees with different ratio of Dikiri/Sugar

\begin{tabular}{|c|c|c|c|c|}
\hline $\begin{array}{c}\text { Sensory } \\
\text { properties, } \\
\text { Toffee }\end{array}$ & $\begin{array}{c}\text { Appearance/ } \\
\text { colour }\end{array}$ & taste & texture & $\begin{array}{c}\text { Overall } \\
\text { acceptability }\end{array}$ \\
\hline A-45\%/55\% & $4.2 \mathrm{a}$ & $4.2 \mathrm{a}$ & $3.9 \mathrm{a}$ & $4.1 \mathrm{a}$ \\
$\mathrm{B}-50 \% / 50 \%$ & $4.3 \mathrm{a}$ & $3.9 \mathrm{a}$ & $3.5 \mathrm{~b}$ & $3.7 \mathrm{~b}$ \\
$\mathrm{C}-55 \% / 45 \%$ & $3.8 \mathrm{~b}$ & $3.8 \mathrm{a}$ & $3.3 \mathrm{~b}$ & $3.5 \mathrm{~b}$ \\
\hline
\end{tabular}

[Note: values in a column followed by same letter are not statistically significant (at 5\%)]

Table 2. Proximate composition of dikiri coconut toffee

\begin{tabular}{|l|l|}
\hline Materials & Mean percentages \\
\hline Moisture & $4.95( \pm 0.09)$ \\
Minerals & $0.81( \pm 0.040)$ \\
Protein & $4.59( \pm 0.14)$ \\
Fat & $16.59( \pm 0.07)$ \\
Fiber & $0.62( \pm 0.06)$ \\
Carbohydrate & 72.44 (by difference) \\
\hline
\end{tabular}

Note: mean value followed by the standard deviation

Table 2 shows the proximate composition of dikiri coconut toffee made with $45 \%$ dikiri and $55 \%$ sugar.

\section{Dikiri Spread}

Sensory evaluation showed that the bread spread made with dikiri coconut received the higher scores for taste and overall acceptability compared with the commercial margarine (control) sample (Table 3). Sample made with margarine showed highest scores for texture 
Table 3. Results of sensory evaluation of Dikiri spread

\begin{tabular}{|l|c|c|c|c|}
\hline \multicolumn{1}{|c|}{$\begin{array}{c}\text { Sensory } \\
\text { properties }\end{array}$} & Appearance/colour & taste & texture & Overall acceptability \\
\hline 1.control & $4.2 \mathrm{a}$ & $3.6 \mathrm{~b}$ & $4.1 \mathrm{a}$ & $3.7 \mathrm{~b}$ \\
2.Dikiri Spread & $4.1 \mathrm{a}$ & $3.9 \mathrm{a}$ & $3.9 \mathrm{~b}$ & $4.2 \mathrm{a}$ \\
\hline
\end{tabular}

[Note: values in a column followed by same letter are not statistically significant (at 5\%)]

Table 4. Proximate composition of Dikiri spread as percentage (Dry weight basis)

\begin{tabular}{|l|c|c|}
\hline \multicolumn{1}{|c|}{ Nutritional components } & Dikiri Spread & Control \\
\hline Moisture & $31.7 \pm 0.2$ & $19.7 \pm 0.3$ \\
Minerals & $7.95 \pm-0.1$ & $5.91 \pm 0.2$ \\
Crude fat & $11.35 \pm 0.3$ & $35.10 \pm 1.2$ \\
Crude protein & $2.68 \pm 0.5$ & $1.12 \pm 0.4$ \\
Crude fibre & $4.95 \pm 0.4$ & $2.94 \pm 0.5$ \\
Carbohydrate (By difference) & 73.07 & 54.93 \\
\hline
\end{tabular}

[Note: values in a column followed by same letter are not statistically significant (at 5\%)]

Table 5. Sensory properties of dikiri Ice cream

\begin{tabular}{|l|c|c|c|c|c|}
\hline \multicolumn{1}{|c|}{ Samples } & Appearance & Taste & Texture & Mouth feel & Overall \\
\hline A & 4.1 & 4.0 & 3.8 & 3.9 & 3.7 \\
Control & 4.0 & 4.0 & 4.0 & 4.0 & 3.9 \\
\hline
\end{tabular}

Note: Average value of 31 scores

Table 6. Components of Dikiri ice cream after three days of manufacturing

\begin{tabular}{|l|c|c|}
\hline \multicolumn{1}{|c|}{ Components } & Dikiri Ice cream & SLSI Standards \\
\hline Total Solids \% by mass & $36.5 \pm 1.8$ & $32 \%$, minimum \\
Fat \% by mass & $10.7 \pm 0.04$ & $8.0 \%$, minimum \\
Acidity as Lactic acid \% by mass & $0.20 \pm 0.01$ & $0.25 \%$, maximum \\
\hline
\end{tabular}

Note: mean value followed by the standard deviation 
compared with dikiri based bread spread and this could be possible due to the degree of fineness of dikiri paste used. Appearance wise, there were no significant differences observed between the tested samples. It is enough to note that the taste of Dikiri spread was rated highest which could be attributed to the fascinating and highly acceptable taste of dikiri detected in bread spread. Similarly, overall quality of dikiri spread was significantly much more acceptable by the sensory panel than that of margarine based bread spread (table 4).

Moisture content of the dikiri spread is about $31.7 \%$ which was considerably higher value compared with margarine based spread (Control), however use of sugar (about 31.0\%) in the recipe can be helpful to keep the water activity of the spread at low level. Margarine is about $80 \%$ fat and $20 \%$ water and solids and mainly provides energy (Nor Aini Idris.et.al, 1996). Crude fibre and mineral content of dikiri spread are significantly higher than margarine based recipe as dikiri coconut is rich in fibre and minerals. Crude protein of the spread and that of the control were $2.68 \%$ and $1.12 \%$, respectively. Even though Dikiri is the major contributor for the provision of crude protein, powdered mustard also contributes for the protein content of the spread since it contains $28-36 \%$ protein (Anon. 2009).

Mustard and pepper in the recipe give sharp pungent flavour, and inhibit the growth of certain yeasts \& moulds, besides imparting emulsifier and antioxidant properties. Turmeric in the recipe gives a natural yellow colour to the final product. Cinnamon and cloves mainly contribute to the flavour profile of the recipe. Both salt and vinegar impart flavour to the bread spread as well as improved keeping quality in general. Tocopherol is the vitamin widely used in the food industry to control the development of rancidity and it exerts its maximum effectiveness relatively at low concentration, approximately 80ppm (Bockish, 1998). So vitamin E was used as the antioxidant in the recipe to extend the shelf life of the product.

\section{Dikiri Ice Cream}

Ice cream is a popular frozen dessert throughout the world. It is a milk-based product with different flavors and types. Dairy ingredients are important for ice cream preparation and it is mainly composed of milk fat and non fat milk solids derived from dairy ingredients plus sugar, stabilizer, emulsifier, flavour materials, water and air. The Dikiri matrix rich in fat and pectin possessing characteristic flavour (Gunathilake, et.al, 2009), thereby being suitable to add value to ice cream. Table 5 shows the results of sensory evaluation of dikiri incorporated ice cream compared with normal dairy ice cream.

The control (regular dairy ice cream) and the Dikiri ice creams were not significantly different for the quality attributes of appearance, taste, texture, mouth feel and overall acceptability $(\mathrm{P}>0.05)$. So that Dikiri coconut can be incorporated into dairy cream for value addition. The composition of the Dikiri added ice cream is shown in table 6 and it shows developed Ice cream conforms to Sri Lanka Standards.

\section{Conclusion}

Dikiri coconut can be utilized successfully for development of variety of food products like Ice cream, Bread Spread and Toffees. Hence, through the commercialization of these products, value adding or added income out of this variety of coconut in Sri Lanka is expected to be enhanced.

\section{Acknowledgement}

The authors are deeply grateful to the CESS FUND for the financial support; Director of Coconut Research Institute for guidance and encouragement; the head and the staff of Tissue Culture Division of Coconut Research Institute for providing experimental samples of Dikiri coconut; and the staff of Coconut Processing Research Division of the institute for various supports. 


\section{References}

AOAC. Official Methods of analysis.1990. Sixteenth edition. AOAC, Inc. Arlington.

Anonymous. 2009. Mustard, available online: http://www.minndak.com/Mustard.htm (Accessed on July 2009)

Arancon, R.N, 1996. Makapuno from the Philippines. Cocoinfo International 3(1):15-17

Bockish, M. (1998). Fats and oil handbook, Second edition, AOCS press, Champaign, Illinois

E.B. Jackson, (1999), Sugar confectionary manufacture, second edition, An Aspen Publication, Maryland, USA.

Gunathilake K.D.P.P., (2009), Nutritional Value of Dikiri Coconut. CORD 25 (2): 56-61
Nor Aini Idris, Leny de Man, T. S. Tang and C. L. Chong.1996. Chemical composition and physical properties of soft (tub) margarines sold in Malaysia, J. American Oil Chemists' Society, 73(8)

Pearson, D. 1973. Laboratory Techniques in Food Analysis, Butterworths \& Co Ltd, London, England

Ranganna, S. 2000. Proximate composition. In handbook of analysis and quality Control for fruits and vegetable products. pp 5-36. Tata and Mc Graw - Hill publishing company Ltd, New Delhi

Sri Lanka Standards Institute Booklet: SLS 223, Specification for Ice Cream. 